
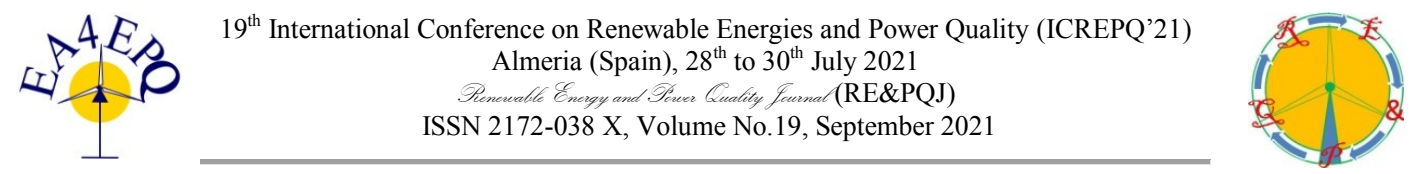

\title{
Study of the second-generation of CdTe and CIGS thin film PV modules under natural sunlight conditions \\ K. Dynda1 ${ }^{1, *}$, J. Sanetra $^{2}$ and K.W. Marszalek ${ }^{1}$
}

\author{
${ }^{1}$ Institute of Electronics, Faculty of Computer Science, Electronics and Telecommunications \\ AGH University of Science and Technology, Al. Mickiewicza 30, Kraków, Poland \\ ${ }^{2}$ The author Jerzy Sanetra is retired. e-mail: pusanetr@cyf-kr.edu.pl \\ Phone: +48 1261756 16, e-mail: *kkoper@agh.edu.pl, marszalek@agh.edu.pl
}

\begin{abstract}
There is a significant amount of research in the literature concerning the performance of solar panels operating during outdoor exposure, but the full topic is not yet exhausted. One of the reasons is that the photovoltaic cell technology is constantly evolving. In this paper, a comparison of two types of CdTe and CIGS modules operated with a nominal power of $80 \mathrm{~W}$ and $140 \mathrm{~W}$, respectively is studied. The module tests were performed under external conditions during autumn, winter, spring, and summer from October 2019 to July 2020 in the temperate climate of Miękinia, South Poland. The photovoltaic panels were connected to the electric grid via microinverters. During the tests, the temperature of the panels was monitored. To determine the influence of solar radiation on the energy conversion efficiency of photovoltaic panels, a pyranometer installed in the plane of the panels was used. Based on the monitoring of the atmospheric conditions and the measurement of instantaneous power, the efficiency of the modules is determined.
\end{abstract}

Key words. Thin film technology, PV modules, CdTe, CIGS, Outdoor measurement

\section{Introduction}

Around the world, demand for electricity is increasing and with demand comes increased pressure to reduce greenhouse gas emissions. This is resulting in a push towards renewable energy sources, which include wind energy, hydropower, tidal energy, geothermal energy, ambient heat captured by heat pumps, biofuels and the renewable part of waste, and solar energy (thermal, photovoltaic and concentrated solar) [1]. Solar energy is one of the most promising renewable energy sources, and photovoltaics $(\mathrm{PV})$ is one of the fastest growing industries [2][3][4]. The development of photovoltaic technology can be classified into three generations. Firstgeneration technology is based on silicon [5]. Secondgeneration cells are thin-film technology [6][7][8][9][10][11]. Third-generation solar cells include organic and dye-sensitized solar cells [12][13]. Despite the fact that silicon technology is very well developed, the use of high temperature, ultra-high vacuum and the complex operation of cutting silicon wafers make this technology inherently complicated. Over the past decade, thin film materials have proved to be potentially suitable for mass production of photovoltaic modules. However, the dynamic development of thin film photovoltaics is slowed down by the decreasing prices of silicon cell production [14]. Nevertheless, thin film technology can be considered as the future of photovoltaic development due to the possibility of obtaining this type of cells on various substrates, such as on flexible substrates and reduction panel weight, which is very important in the case of installations on the roofs of buildings or in the outer space [15]. Modules made of second generation cells are characterized by the fact that the semiconductor material is applied as a thin film (only a few micrometers). The three major thin film photovoltaic technologies in the market are a-Si (amorphous silicon), CIGS (Copper Indium Gallium and Selenide) [16][17] and CdTe (Cadmium Telluride) [18], which the oldest is the first of them. Among these, CdTe and CIGS modules achieves the highest efficiency compared to the amorphous silicon. Solar cell CIGS and CdTe efficiency are $23.3 \%$ and $21.0 \%$, respectively [19][20]. The electrical characteristic parameters are provided by manufacturers of photovoltaic modules in the safety data sheets. However, this specification is generally referred to standard test conditions (STC: irradiance $1000 \mathrm{~W} / \mathrm{m}^{2}$, cell temperature $25{ }^{\circ} \mathrm{C}$, air mass AM 1.5 and zero incidence angle), which differ significantly from the actual operating conditions of the PV system [21] Due to this, it is important to test $\mathrm{PV}$ modules under real working conditions. There is a lot of work focused on studying the efficiency and electrical parameters of solar panels operating in various regions around the world but this subject is not yet exhausted [22][23]. One of the reasons is that photovoltaic cell technology is constantly evolving. In the following papers it has been proved that the efficiency of photovoltaic systems depends on the location [24][25][26], weather [27] and angles of surface orientation in relation to the horizon and azimuth [28][29][30]. The objective of this paper is to add to this area of study with an analysis of the CdTe and CIGS modules fabricated by thin film technology working in the temperate climate. The power generated of each module was determined. This work presents the results of tests performed for four months in autumn, winter, spring and summer using a monitoring facility the work of the panels under current operating conditions such as temperature and solar radiation. The temperature of the module and solar radiation are very important parameters that affect the PV efficiency [31]. 


\section{Experimental setup}

\section{A. The study location}

The photovoltaic system under study is installed in the Photovoltaic Laboratory located in the area of the AGH-UST Educational and Research Laboratory of Renewable Energy Sources and Energy Saving in Miękinia near Krzeszowice, Poland (5009'37.4”N $\left.19^{\circ} 36^{\prime} 04.7^{\prime \prime} \mathrm{E}\right)$. Miękinia is located in a warm, temperate and transient climate, so it is characterized by variable and various types of weather.

\section{B. Description of the Photovoltaic and Monitoring System}

The tests were performed for two different thin film photovoltaic modules, i.e. two CdTe modules (ASP, China) and three CIGS modules (TSMC Solar, Germany) each of them with nominal power of $80 \mathrm{~W}$ and $140 \mathrm{~W}$. Table I is shown their main technical characteristics.

Table I. Electrical characteristic of photovoltaic modules at standard test condition

\begin{tabular}{|c|c|c|}
\hline \multirow{2}{*}{ Parameters } & \multicolumn{2}{|c|}{ Module type } \\
\hline & $\mathrm{CdTe}$ & CIGS \\
\hline Module type/Producer & $\begin{array}{l}\text { ASP- } \\
\text { S1-80, } \\
\text { ASP }\end{array}$ & $\begin{array}{l}\text { TS- } \\
\text { 140C1, } \\
\text { TSMC } \\
\text { SOLAR }\end{array}$ \\
\hline Power $( \pm 5 \%)(\mathrm{W})$ & 80 & 140 \\
\hline Number of panel per PV array & 3 & 2 \\
\hline Total power of PV array [W] & 240 & 280 \\
\hline Open-Circuit Voltage (V) & 118 & 63.1 \\
\hline Short-Circuit Voltage (A) & 0.98 & 3.50 \\
\hline Voltage at $P_{\max }(\mathrm{V})$ & 92 & 45.3 \\
\hline Current at $P_{\max }(\mathrm{V})$ & 0.86 & 3.09 \\
\hline Maximum system Voltage (V) & 1000 & 1000 \\
\hline Temperature power coefficient & 0.06 & 0.01 \\
\hline Area of PV module $\left[\mathrm{m}^{2}\right]$ & 2.16 & 2.17 \\
\hline
\end{tabular}

a)

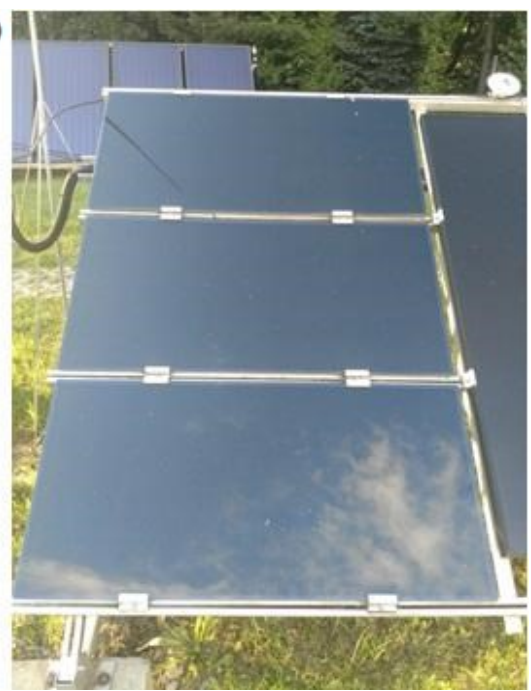

The photovoltaic modules of the different technologies are coplanar with a tilt of $30^{\circ}$ to the horizontal ground surface and faced south. The system of photovoltaic modules used for the tests is shown in Fig. 1. All PV modules have been connected to the electrical grid with 220-Watt microinverters Micro Replus-250 (Renesola Deutschland GmbH, Germany). The photovoltaic system also included meters of DC network parameters NEMO D4 DC (IME, Italy), which allowed measurement of the modules voltage, current and power. In order to measure the intensity of solar radiation, the LP PYRA 03 AC Pyranometer was used.

The temperature of the modules was measured and recorded using PT100 temperature sensors (Heraeus Nexensos GmbH, Germany) located on the back of the modules and the MPI-8-T-1-0 (METRONIC) temperature recorder. The measured parameters were saved using the mLog program (Metronic AKP Ltd., Poland) in one of the four months, i.e. October, December in 2019 and March and July in 2020. In this work, the results for the chosen four days from each of that month are presented.

\section{Results and Discussion}

Daily solar radiation variation for chosen one day in October, December, March and July are shown in Fig. 2. On the basis of the obtained results, it can be concluded that in March the sky was cloudless, as there are no rapid changes in the solar radiation. In July, the chart rapidly changes. It was caused by cloudy skies what the weather data clearly shows. Similar conclusions can be drawn for the solar radiation results from the December day. In October, the solar radiation was typical for a cloudless day, except for the afternoon hours. We can see a sharp decrease in the recorded solar radiation, which could be caused by temporary cloudiness or other shadings of the pyranometer, for example by employees of the Photovoltaic Laboratory. The temperature obtained by the PV modules during the selected day in October, as well as the solar radiation values are presented in Fig. 3.

b)

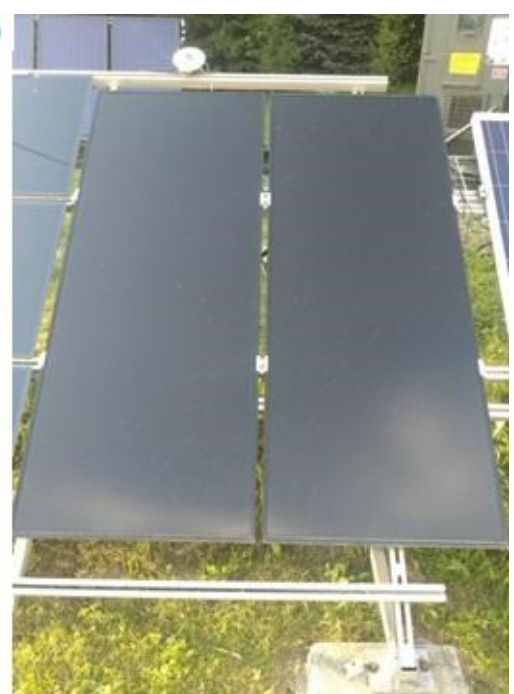

Fig. 1. a) CdTe and b) CIGS photovoltaic modules in the Photovoltaic Laboratory in Miękinia 


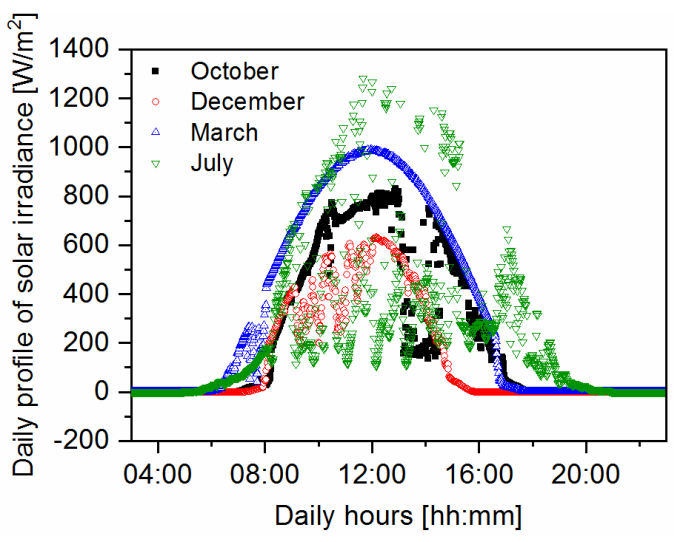

Fig. 2. Daily profile of solar radiation on chosen one day of the October, December, March and July

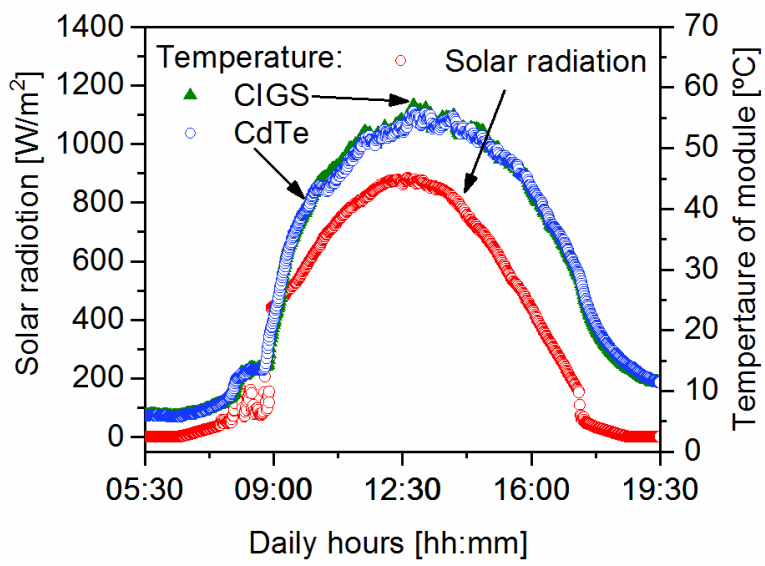

Fig. 3. Daily profile of temperature and solar radiation of CIGS and CdTe modules on one chosen day of the October
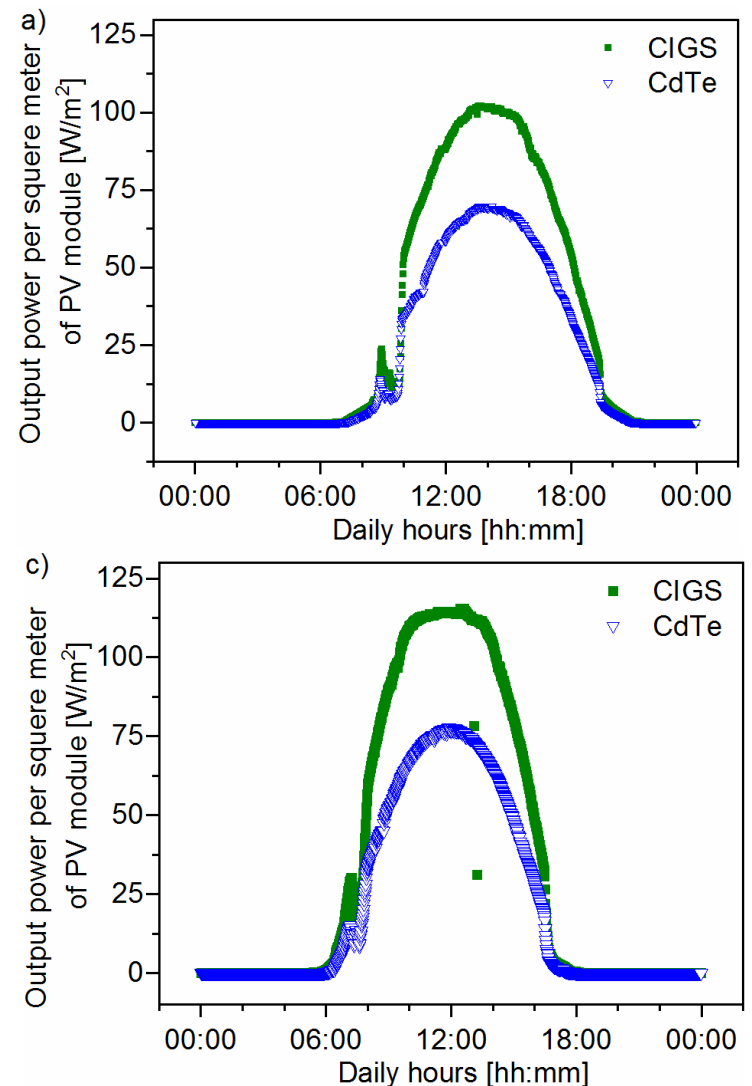

The highest solar radiation among chosen days was in July and its maximum value was $1280 \mathrm{~W} / \mathrm{m}^{2}$. Whereas, in March, October and December the solar radiation was $986 \mathrm{~W} / \mathrm{m}^{2}, 877 \mathrm{~W} / \mathrm{m}^{2}$ and $627 \mathrm{~W} / \mathrm{m}^{2}$, respectively. The measurement results show that the temperature of the modules strongly depends on the solar radiation. The CIGS modules heat up slightly more $\left(57^{\circ} \mathrm{C}\right.$ at $\left.12: 30\right)$ than CdTe modules $\left(55^{\circ} \mathrm{C}\right.$ at 12:30) under the same solar radiation conditions. The results of measurements of solar radiation and module temperature, due to seasonal fluctuations under moderate climate, indicate that the STC conditions used for testing PV modules are rarely met. The CIGS photovoltaic modules are considered to be one of the most efficient as the highest light-to-power conversion efficiency material [8]. This fact was confirmed by the results of tests carried out at the Photovoltaic Laboratory in Miękinia. Fig. 4 presents examples of power profiles generated by PV modules (CIGS and CdTe) in relation to the unit area obtained during one day of October, December, March and July. The highest power generated per square meter of a module was obtained in July, March, October and December, respectively. For CIGS modules, the maximum values of generated power on selected days were as follows: $121 \mathrm{~W} / \mathrm{m}^{2}$ (July), $114 \mathrm{~W} / \mathrm{m}^{2}$ (March), $102 \mathrm{~W} / \mathrm{m}^{2}$ (October) and $83 \mathrm{~W} / \mathrm{m}^{2}$ (December). In the case of CdTe modules, the values of generated output power was $104 \mathrm{~W} / \mathrm{m}^{2}$, $77 \mathrm{~W} / \mathrm{m}^{2}, 69 \mathrm{~W} / \mathrm{m}^{2}$ and $48 \mathrm{~W} / \mathrm{m}^{2}$ on the chosen day of July, March, October and December, respectively.
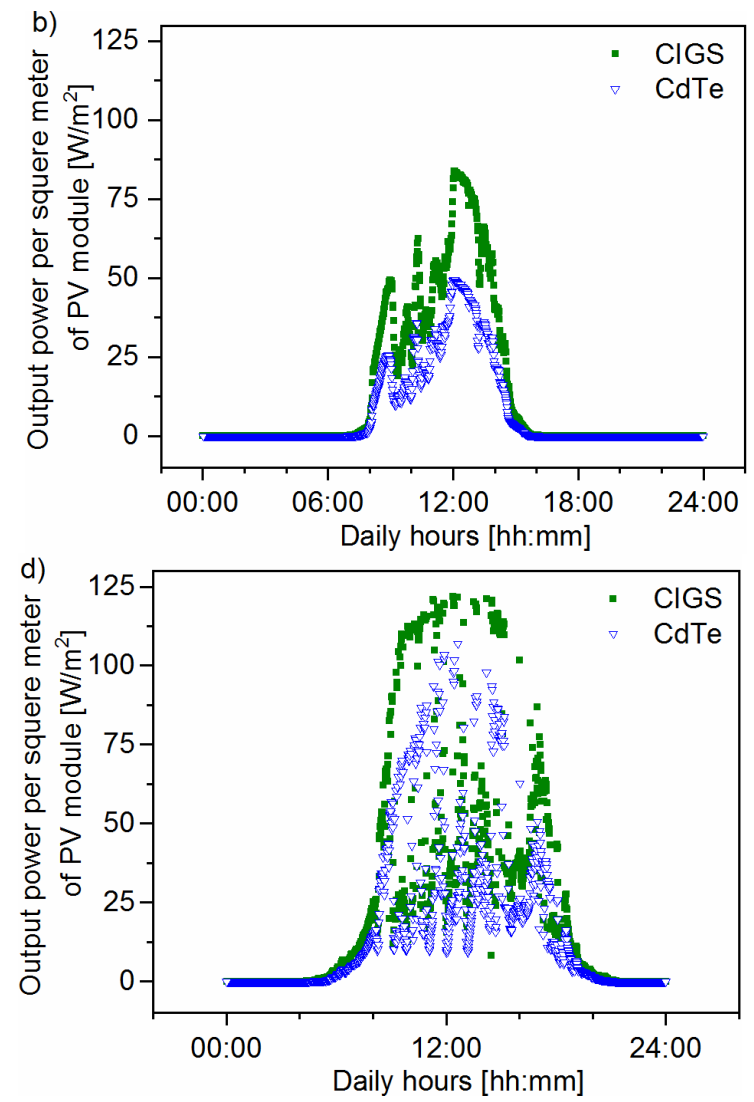

Fig. 4. Examples daily profiles of power generated by particular PV arrays regarding to unit surface area 


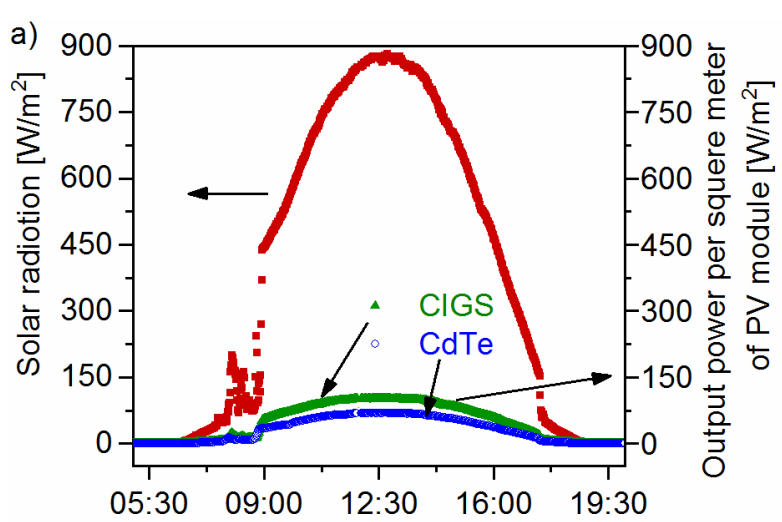

Daily hours [hh:mm]

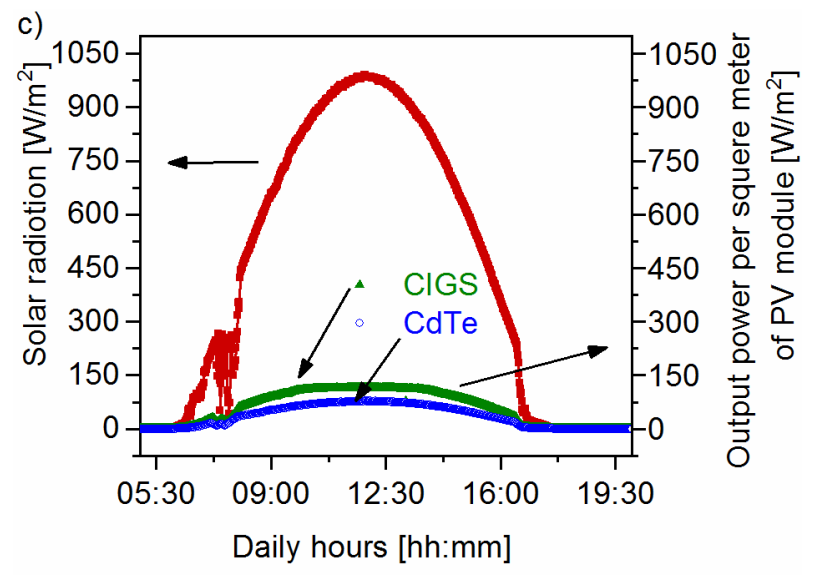

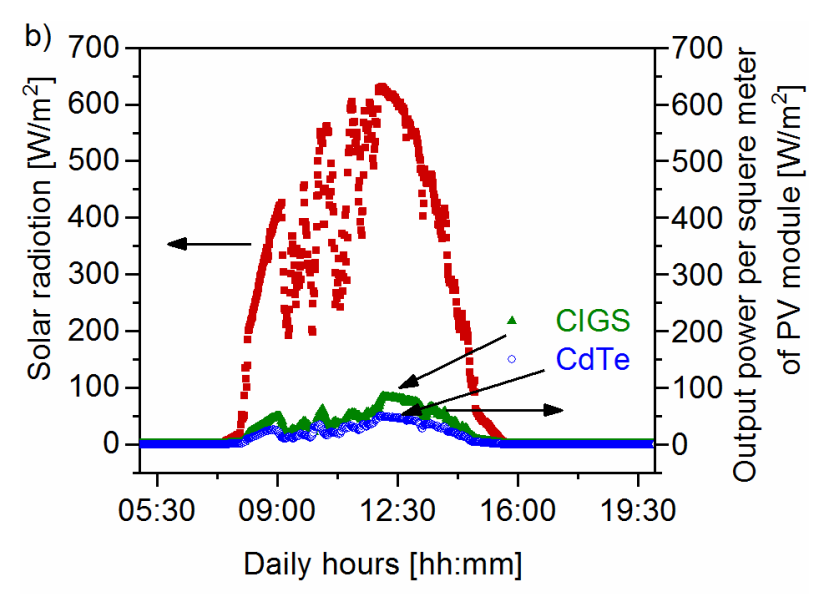

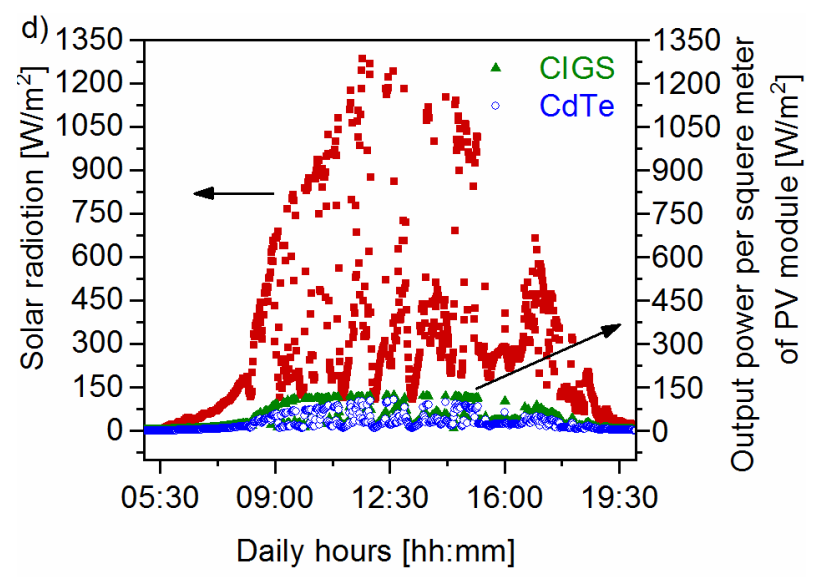

Fig. 5. Examples of daily profiles of solar radiation and output power per square meter PV modules for CIGS and CdTe modules in one chosen day in different months of the year a) October, b) December, c) March and d) July

Daily profiles of solar radiation and output power per square meter PV modules in one chosen day in different months of the year are presented in Fig. 5. The efficiency of PV modules, which can be defined as a fraction of solar energy falling on the panel and converted into electricity, is shown in Fig. 6. The figures compare the efficiency of CIGS and CdTe modules on chosen days. The efficiency of CIGS modules is about $13 \%$, while in the case of CdTe modules this value is lower, as it is about $8 \%$. Changes in performance can be correlated with the susceptibility of modules to heating. The lowest influence of operating temperature is observed in the case of CdTe modules. The efficiency PV module depending on PV module temperatures are presented in Fig. 7. This figure shows that the increased temperature causes the efficiency of output power generated throughout CIGS module decrease. In the case of the CdTe modules, changing temperature does not significantly affect their efficiency. This means that the highest insolation does not always lead to an increase in the generated output power. High solar radiation can lead to an increase in the generated output power, while the influence of the panel temperature on the efficiency can be so high that it can reduce it.

\section{Conclusion}

The of CIGS and CdTe modules. The tests were conducted paper presents the results of the long term tests of two types under natural sunlight conditions. Results show that the CIGS and CdTe PV module's efficiency is affected by the increase in the temperature of modules. The lowest influence of operating temperature is observed in the case of CdTe modules. Based on the research results, it can be concluded that it is difficult to obtain the module efficiency declared by the producer. It is related to the operation of modules under real conditions, which are different from those of STC. Therefore, it is very important to test PV modules under real sunlight conditions.

\section{Acknowledgement}

This work was supported by AGH University project 16.16.230.434. 
a)

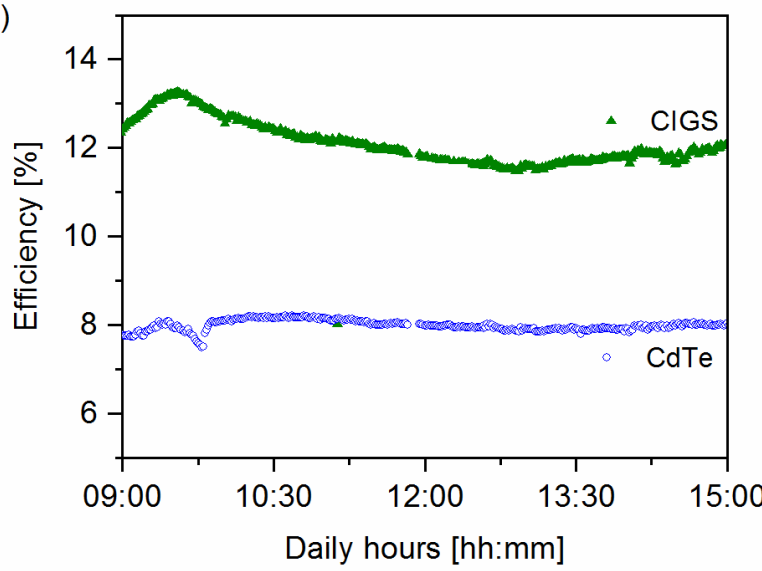

c)

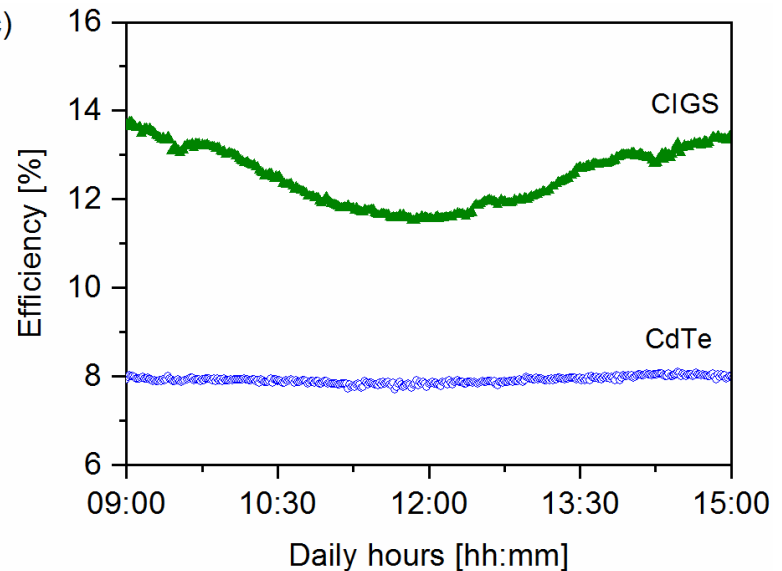

b)

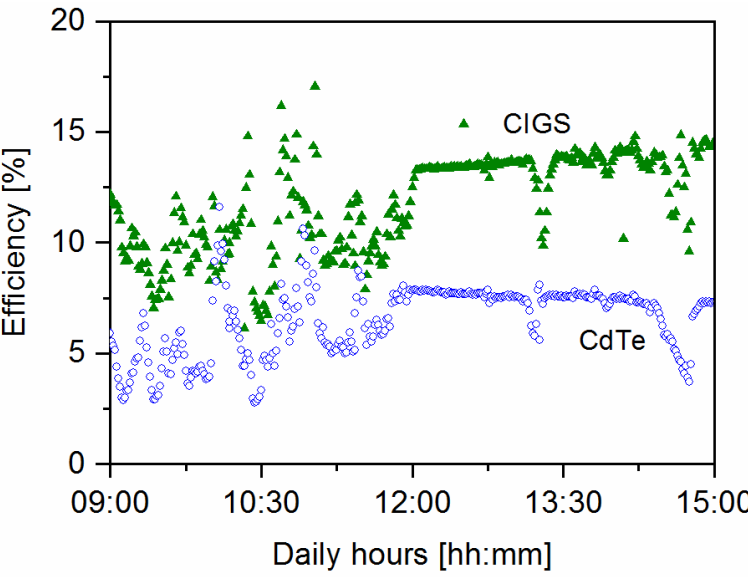

d)

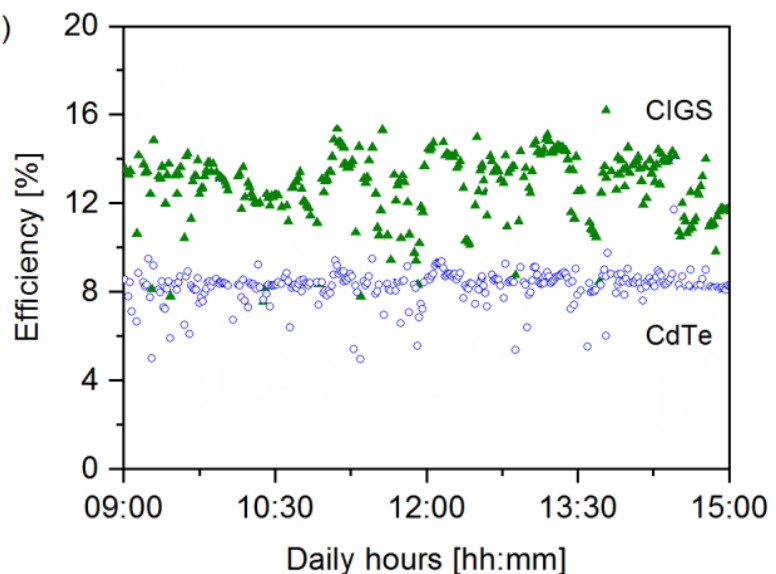

Fig. 6. Examples daily profiles of power generated by particular PV arrays regarding to unit surface area during one day of a) October, b) December, c) March and d) July

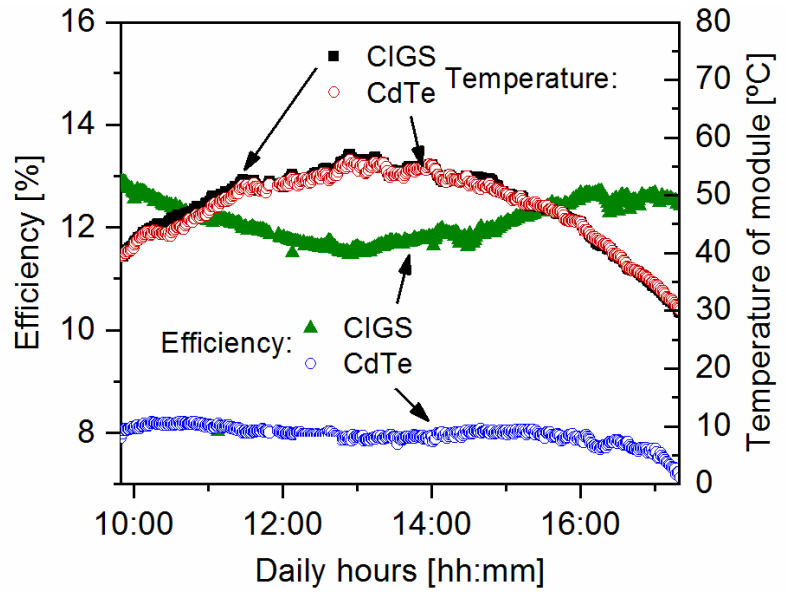

Fig. 7. Influence of module temperatures on their efficiency in chosen one day of the October

\section{References}

[1] T. Ahmad and D. Zhang, "A critical review of comparative global historical energy consumption and future demand: The story told so far", Energy Reports, vol. 6, pp, 1973-1991, 2020.

[2] J. Jurasz, F. A. Canales, A. Kies, M. Guezgouz and A. Beluco, "A review on the complementarity of renewable energy sources: Concept, metrics, application and future research directions", Sol. Energy, vol. 195, pp. 703-724, 2020.
[3] B. J. van Ruijven, E. D. Cian, I. S. Wing, Amplification of future energy demand growth due to climate change," Nat. Commun., vol. 10, pp. 1-12, 2019.

[4] REN21, Renewable 2020 Global status report, Estimated Renewable Share of Total Final Energy Consumption, 2020. [Online]. Available: https://www.ren21.net/wpcontent/uploads/2019/05/gsr_2020_full_report_en.pdf 
[5] A. Khatibi, F. R. Astaraei and M. H. Ahmadi, "Generation and combination of the solar cells: A current model review," Energy Sci. Eng., vol. 7, pp. 305-322, 2019.

[6] J. Cao and F. Yan, "Recent progress in tin-based perovskite solar cells ," Energy Environ. Sci., vol. 14, pp. 12861325, 2021.

[7] T. D. Lee and A. U. Ebong, "A review of thin film solar cell technologies and challenges," Renew. Sust. Energ. Rev., vol. 70, pp. 1286-1297, 2017.

[8] M. A. Almeida, "Recent advances in solar cells," Solar Cells: Springer, pp. 79-122, 2020.

[9] M. M. A. Moon, M. F. Rahman, J. Hossain, and A. B. M. Ismail, "Comparative Study of the Second Generation a-Si:H, CdTe, and CIGS Thin-Film Solar Cells," Adv. Mater. Res., vol. 1154, pp. 102-111, 2019.

[10] C. B. Isabela, R. A. M. Lameirinhas, J. P. N. Torres and C. A. F. Fernande, "Comparative study of the copper indium gallium selenide (CIGS) solar cell with other solar technologies," Sustain. Energ. Fuels, vol. 5, pp. 2273-2283, 2021.

[11] D. Devadiga, M. Selvakumar, P. Shetty and M. S. Santosh, "Dye-Sensitized Solar Cell for Indoor Applications: A Mini-Review," Journal of Elec. Materi., 2021. [Online]. Available: https://link.springer.com/content/pdf/10.1007/s11664021-08854-3.pdf

[12] A. E. Touihri, T. Azizi and R. Gharbi, "Transient current effect on the dye sensitized solar cells I-V characterization," IET Sci. Meas. Technol., vol. 15, pp. 70-76 2020.

[13] M. Powalla, S. Paetel, E. Ahlswede, R. Wuerz, C. D. Wessendorf, and T. Magorian Friedlmeier, "Thin-film solar cells exceeding 22\% solar cell efficiency: An overview on CdTe-, $\mathrm{Cu}(\mathrm{In}, \mathrm{Ga}) \mathrm{Se}_{2}$-, and perovskite-based materials," Appl. Phys. Rev., vol. 5, pp. 1-30, 2018.

[14] A. Jäger-Waldau, "Snapshot of photovoltaics - February

2019”, Energies, vol. 12, pp. 1-7, 2019.

[15] El-Atab and M.M. Hussain, „Flexible and stretchable inorganic solar cells: Progress, challenges, and opportunities”, MRS Energy \& Sustainability, vol. 7, pp. 1-23, 2020.

[16] S. R. F. S. Panahi, A. Abbasi, V. Ghods and M. Amirahmadi, "Analysis and improvement of CIGS solar cell efficiency using multiple absorber substances simultaneously," J. Mater. Sci.: Mater. Electron., vol. 31, pp. 11527-11537, 2020.

[17] A. Bosio, S. Pasini, and N. Romeo, "The History of Photovoltaics with Emphasis on CdTe Solar Cells and Modules," Coatings, vol. 10, pp. 1-30, 2020.

[18] M. Green, E. Dunlop, J. Hohl-Ebinger, M. Yoshita, N. Kopdakis and X. Hao, "Solar cell efficiency tables (version 57)," Prog. Photovolt. Res. Appl., vol. 29, pp. 3-15, 2021.

[19] R. Noufi and K. Zweibel, "The 2020 photovoltaic technologies roadmap," J. Phys. D: Appl. Phys., vol. 53, pp. 493001, 2020.

[20] M. A. Muñoz-García, O. Marin, M. C. Alonso-García, and F. Chenlo, "Evaluation of solar module equivalent models under real operating conditions - A review," Renew. Sust. Energ. Rev., vol. 12, pp. 012701, 2020.

[21] G. A. Thopil, C. E. Sachse, J. Lalk, and M. S. Thopil, "Techno-economic performance comparison of crystalline and thin film PV panels under varying meteorological conditions: A high solar resource southern hemisphere case," Appl. Energy, vol. 275 , p. 115041, 2020.

[22] N. A. S. Elminshawy, A. M. I. Mohamed, K. Morad, Y. Elhenawy, and A. A. Alrobaian, "Performance of PV panel coupled with geothermal air cooling system subjected to hot climatic," Appl. Therm. Eng., vol. 148, pp. 1-9, 2019.

[23] S. S. Korsavi, Z. S. Zomorodian, and M. Tahsildoost, "Energy and economic performance of rooftop PV panels in the hot and dry climate of Iran," J. Clean. Prod., vol. 174, pp. 12041214, 2018.

[24] W. Luboń, G. Pełka, K. Marszałek, and A. Małek, "Performance Analysis of Crystalline Silicon and CIGS
Photovoltaic Modules in Outdoor Measurement," Ecol. Chem. Eng. S, vol. 24, pp. 539-549, 2017.

[25] M. J. . Buni, A. A. K. Al-Walie, and K. A. N. AlAsadi, "Effect of Solar Radiation on Cetaceans," Int. Res. J. Adv. Eng. Sci., vol. 3, pp. 47-51, 2018.

[26] S. Seme, K. Sredensek, B. Stumberger and M. Hadziselimovic, "Analysis of the performance of photovoltaic systems in Slovenia," Sol. Energy, vol. 180, pp. 550-558, 2019. [27] A. A. Hachicha, I. Al-Sawafta and Z. Said, "Impact of dust on the performance of solar photovoltaic (PV) systems under United Arab Emirates weather conditions," Renew. Energy, vol.141, pp. 287-297, 2019.

[28] M. Z. Jacobson and V. Jadhav, "World estimates of PV optimal tilt angles and ratios of sunlight incident upon tilted and tracked PV panels relative to horizontal panels," Sol. Energy, vol. 169, pp. 55-66, 2018.

[29] T. M. Y. Khan, M. E. M. Soudagar, M. Kanchan, A. Afzal, N.R. Banapurmath, N. Akram, S. D. Mane and K. Shahapurkar, "Optimum location and influence of tilt angle on performance of solar PV panels," J. Therm. Anal. Calorim., vol. 141, pp. 1-23, 2019.

[30] M. A. A. Mamun, M. M. Islam, M. Hasanuzzaman and J. Selvaraj, "Effect of tilt angle on the performance and electrical parameters of a PV module: Comparative indoor and outdoor experimental investigation," Energy and Built Environment., In Press, Corrected Proof, 2021.

[31] M. Ali, H. M. Ali, W. Moazzam and M. B. Saeed, "Performance enhancement of PV cells through micro-channel cooling," AIMS Energy., vol. 3, pp. 699-710, 2015. 